\title{
Prevention of vertical transmission of the bacterial kidney disease agent Renibacterium salmoninarum by broodstock injection with erythromycin
}

\author{
E. G-H. Lee ${ }^{1}$, T. P. T. Evelyn ${ }^{2}$ \\ ${ }^{1}$ British Columbia Research Corporation, 3650 Wesbrook Mall, Vancouver, British Columbia, Canada V6S 2 L2 \\ ${ }^{2}$ Department of Fisheries and Oceans, Biological Sciences Branch, Pacific Biological Station, Nanaimo, British Columbia, \\ Canada V9R 5K6
}

\begin{abstract}
Seemingiy healthy coho salmon Oncorhynchus kisutch that had returned from the sea to spawn in a British Columbia hatchery were transferred to the laboratory where the females were infected by intraperitoneal injection with a heavy suspension of Renibacterium salmoninarum (Rs), causative agent of bacterial kidney disease (BKD). Five days later, half of the infected females were injected (via the dorsal sinus) with erythromycin (20 mg drug per $\mathrm{kg}$ fish) and the other half (untreated controls) were injected with saline. Following spawning 28 d later, eggs were collected from 5 of the treated and 5 of the control females. The eggs were then fertilized with milt pooled from 3 males that, on the basis of gross and microscopic examination, appeared to be Rs-free. The eggs were then incubated in trays until hatching. Yolk samples from eyed eggs and alevins derived from the treated females contained erythromycin ( 1.0 to $1.6 \mu \mathrm{g} \mathrm{m}]^{-1}$ and 0.6 to $0.7 \mu \mathrm{g} \mathrm{ml}^{-1}$, respectively); analogous samples from the untreated females lacked the antibiotic. None of the 5 fish treated with erythromycin yielded Rs-positive eggs or alevins. In contrast, all of the untreated females yielded infected eggs $(8$ to $22 \%$ Rs-positive, intra-ovum) and alevins (from each female, there were 1 to 3 Rs-positive 10 -alevin pools per 10 pools tested). Tests for Rs were based on culture (eggs) or on the membrane filtration-indirect fluorescent antibody technique. The significance of these results for the control of BKD is discussed.
\end{abstract}

KEY WORDS: Renibacterium salmoninarium - Bacterial kidney disease · Vertical transmission · Control

\section{INTRODUCTION}

Bacterial kidney disease (BKD), caused by Renibacterium salmoninarum (Rs), is the most important infectious disease affecting farmed salmon in British Columbia (B.C.), Canada. Control of the disease by chemotherapy is unsatisfactory, and control by vaccination is still not feasible (Evelyn 1988, Elliott et al. 1989).

The infection can be transmitted horizontally in both fresh and sea water (Bell et al. 1984, Murray et al. 1992) but the initial source of infection for fish in any given population is the female spawner which can vertically transmit the pathogen to its progeny via the egg (Bullock et al. 1978, Evelyn et al. 1984a, b, 1986b). In
B.C., Rs-infected eggs are thought to be a major source of the infection for the salmon farming industry. However, efforts to break the infection cycle at the egg stage by selecting Rs-free fish as egg sources have not been particularly successful, partly because the immunofluorescence-based Rs detection techniques that have been routinely used were too insensitive to detect all Rs-infected brood individuals (Pascho et al. 1987, Armstrong et al, 1989b).

In view of the foregoing, the present experiment was undertaken to investigate whether vertical transmission of the pathogen could be prevented using the 'broodstock injection technique'. In this procedure, female salmon are injected with erythromycin ca 9 to $56 \mathrm{~d}$ prior to spawning. During this period, the fish de- 
posit therapeutic levels of the antibiotic in their eggs (Bullock \& Leek 1986, Evelyn et al. 1986a, Armstrong et al. 1.989a, Brown et al. 1990). In the present experiment, we tested the hypothesis that the levels of intraovum antibiotic attained were sufficiently high and persisted long enough to kill any Rs cells being carried within the eggs.

\section{MATERIALS AND METHODS}

Experimental fish. Apparently healthy coho salmon Oncorhynchus kisutch returning from the sea to spawn were collected at the Chilliwack Hatchery, Chilliwack, B.C., ca 5 wk before their expected spawning time. The fish ranged in welght from $1 . \overline{9}$ to $2.5 \mathrm{~kg}$. Five males and 25 females were transported by helicopter to the B.C. research laboratory, the fish being held in 320 I of water containing $0.3 \mathrm{ppm}$ of the sedative Marinil (Syndel Laboratories Ltd, Vancouver, B.C.) during transport.

Upon arrival at the laboratory, all of the females were experimentally infected with Rs by injecting each of them intraperitoneally (IP) with $1 \mathrm{ml}$ of saline containing $2.4 \times 10^{8}$ viable Rs cells. Males were not injected with the pathogen. After $5 \mathrm{~d}$ of holding (during which time the Rs cells had the opportunity to become intracellular and systemic in the fish), half of the females were injected between the epaxial muscles just anterior to the dorsal fin ('the dorsal sinus') with erythromycin in saline $(20 \mathrm{mg}$ erythromycin base per $\mathrm{kg}$ fish) (Sigma Chemical Co., St. Louis, Mo. USA.). The remaining females served as untreated controls and were injected IP with saline $(1 \mathrm{ml})$. The treated and untreated females were kept in separate tanks in flowing dechlorinated city water at 8 to $9^{\circ} \mathrm{C}$ and were monitored regularly for their readiness to spawn.

Eggs were taken from the first 5 treated and 5 untreated fish that proved to be ripe. The eggs from the fish were collected in clean, separate containers. All of the remaining spawners were discarded. All eggs were fertilized with milt pooled from 3 of the ripe males. These males all appeared to be Rs-free based on gross appearance and on an examination of kidney smears by use of the indirect immunofluorescent antjbody technique (IFAT) (Lee \& Gordon 1987).

Fertilized eggs from the treated and untreated spawners were incubated in Heath trays ( 1 tray per spawner in separate stacks and supplied with dechlorinated city water at 4 to $8^{\circ} \mathrm{C}$ until hatching. At the eyed egg stage and at hatching, samples of the eggs and alevins, respectively, were collected and examined for their antibiotic content and for the presence of Rs as outlined below.
Determination of erythromycin in eyed eggs and alevins. To determine the erythromycin levels within the eggs and alevins, yolk material from 10 eyed eggs (96 d post-drug-injection) and 10 alevins (123 to $133 \mathrm{~d}$ post-drug-injection) from each spawner was collected and individually analyzed for the drug by a microbiological assay (Evelyn et al. 1986a). The yolk material was removed from the eggs and alevins using a 25 gauge $1.5 \mathrm{~cm}$ hypodermic needle attached to a $1 \mathrm{ml}$ syringe.

Detection of Rs in eggs. Some 150 eyed eggs (101 d post-infection) were randomly collected from each spawner and assayed for the presence of intra-orum Rs. The eggs were surface-disinfected for $15 \mathrm{~min}$ in $500 \mathrm{ppm}$ aqueous iodine (supplied by Ovadine $\mathbb{B}$; Syndel Laboratories Ltd, Vancouver, B.C.). The surface-disinfected eggs were then rinsed 3 times with sterile water and placed in tubes containing $5 \mathrm{ml}$ of KDM2 broth (1 egg per tube). After remaining in the broth for ca $30 \mathrm{~min}$ (the time required to load 100 eggs into the test tubes), the eggs were shocked by vigorous vortexing for 15 to $20 \mathrm{~s}$ to permit entry of the broth nutrients into the eggs and to ensure that the eggs would release any intra-ovum antibiotic to the medium. During the next 30 min, the eggs became opaque and the broth tubes were frequently agitated to distribute the released antibiotic evenly in the broth (final dilution of the released antibiotic in the broth would have been 1:50). This procedure ensured that Rs cells did not experience any significant in vitro exposure to antibiotic concentrations high enough to be bactericidal, a fact that had been established by antibiotic assays on similarly treated eggs in an earlier trial. The broth tubes were then incubated at $15^{\circ} \mathrm{C}$ for 6 wk to enrich the numbers of any viable Rs cells present in the eggs (Evelyn et al. 1984a, b). An egg was considered to be surface-sterile and suitable for intra-ovum sampling if the broth surrounding it remained clear and proved free of Rs cells by the membrane filtration-IFAT (MFIFAT) (Elliott \& Barila 1987). One hundred such eggs (of each 150 collected) were actually tested for intraovum Rs.

To determine whether Rs cells occurred within the eggs, each surface-sterile egg was aseptically removed from the KDM2 broth, rinsed twice with sterile water, and transferred to $5 \mathrm{ml}$ of sterile KDM2 broth in a test tube where it was broken with a pair of sterile forceps. Each tube was incubated for another $6 \mathrm{wk}$ at $15^{\circ} \mathrm{C}$. The contents of any tubes with bacterial growth were then cultured on KDM2 agar for $14 \mathrm{~d}$ at $15^{\circ} \mathrm{C}$ and growth occurring on the plates was examined to confirm that it was Rs (Gram stain, motility test, and IFAT reaction).

Detection of Rs in alevins. To detect Rs within alevins (128 to $138 \mathrm{~d}$ post-infection), yolk material was aseptically removed from alevins that had been 
Table 1. Oncorhynchus kisutch. Erythromycin (E) levels and Renibacterium salmoninarum (Rs) prevalence in the yolk of eggs and alevins derived from E-treated and saline-treated Rs-infected females. Females were injected via the 'dorsal sinus' with E (20 mg per $\mathrm{kg}$ fish) $28 \mathrm{~d}$ prior to spawning

\begin{tabular}{|c|c|c|c|c|c|}
\hline \multirow{2}{*}{$\begin{array}{l}\text { Pre-spawning } \\
\text { treatment }\end{array}$} & \multirow{2}{*}{$\begin{array}{c}\text { Spawner } \\
\text { number }\end{array}$} & \multicolumn{2}{|c|}{$E_{\text {level }}^{\mathrm{a}}$} & \multicolumn{2}{|c|}{ Rs prevalence ${ }^{b}$} \\
\hline & & Eggs & Alevıns & Eggs & Alevins \\
\hline & 1 & $1.6( \pm 0.3)$ & $0.6( \pm 0.2)$ & 0 & 0 \\
\hline E injected $5 \mathrm{~d}$ after & 2 & $1.0( \pm 0.3)$ & $0.7( \pm 0.2)$ & 0 & 0 \\
\hline \multirow{4}{*}{ Rs injection } & 3 & $1.1( \pm 0.2)$ & $0.7( \pm 0.2)$ & 0 & 0 \\
\hline & 4 & $1.3( \pm 0.3)$ & $0.6( \pm 0.2)$ & 0 & 0 \\
\hline & 5 & $1.1( \pm 0.3)$ & $0.7( \pm 0.2)$ & 0 & 0 \\
\hline & 6 & 0 & 0 & 15 & 20 \\
\hline Saline-injected $5 \mathrm{~d}$ & 7 & 0 & 0 & 19 & 30 \\
\hline after Rs-injection & 8 & 0 & 0 & 11 & 10 \\
\hline \multirow[t]{2}{*}{ (Controls) } & 9 & 0 & 0 & 22 & 20 \\
\hline & 10 & 0 & 0 & 8 & 30 \\
\hline
\end{tabular}

euthanized in tricaine methane sulfonate (Syndel Laboratories Ltd., Vancouver, B.C.) and then surfacedisinfected as for the eggs. The yolk material from 10 alevins (ca $0.6 \mathrm{ml}$ ) was pooled into 1 sample and the sample was diluted with $5 \mathrm{ml}$ of sterile saline. Ten such alevin pools were prepared from each brood fish and 1 $\mathrm{ml}$ of each diluted sample was examined for Rs by use of the MF-IFAT (Lee 1989).

\section{RESULTS AND DISCUSSION}

Our results (Table 1) confirm those of a number of others (already cited) that the prespawning injection of female salmon with erythromycin can result in therapeutic levels of the drug in the yolk of the resulting eggs and alevins. In the present case, the prespawning injection was administered $28 \mathrm{~d}$ before spawning, well within the time frame earlier established as necessary for drug deposition in eggs. The data in Table 1 represent the average levels of drug found in the yolk of eyed eggs ( 1.0 to $1.6 \mu \mathrm{g} \mathrm{ml}^{-1}$ ) and in the yolk of alevins $\left(0.6\right.$ to $\left.0.7 \mu \mathrm{g} \mathrm{ml}^{-1}\right)$, and they indicate that the drug levels persisted well in the yolk, dropping by only $50 \%$ by the alevin stage. This slow decline in the yolk levels of the drug was consistent with that found in earlier studies (Bullock \& Leek 1986, Armstrong et al. 1989a, Brown et al. 1990). The actual range of drug levels found in the eyed eggs and in alevins was 0.5 to 2.0 and 0.3 to $1.0 \mu \mathrm{g} \mathrm{ml}^{-1}$ yolk, respectively (data not shown in Table 1). Significantly, however, the lowest concentrations of drug present in the eggs and alevins equalled or exceeded the $0.3 \mu \mathrm{g} \mathrm{m \textrm {m } ^ { - 1 }}$ level found in vitro to be lethal for Rs (Evelyn et al 1986a).
The results (Table 1) indicate that all 5 fish challenged with Rs prior to spawning yielded Rs-infected eggs and alevins if they did not subsequently receive an injection of erythromycin: 8 to $22 \%$ of the eggs and 1 to 3 of the 10,10 -alevin pools derived from each female were Rs-infected. In contrast, all 5 females that were treated with erythromycin following the prespawning challenge with Rs yielded Rs-free eggs and alevins. These promising results suggest that the broodstock injection technique should be a highly effective procedure for preventing the vertical transmission of Rs, and they support the findings of others (Evelyn et al. 1986a, Armstrong et al. 1989a, Brown et al. 1990) which suggested that this should be the case. The present study is, however, the first to incorporate the following combination of features in the experimental design: the use of an egg infection process simulating that of the natural process; the use of eggs that were surface-sterile, thus ruling out the possibility that surface-borne Rs cells affected the outcome of the experiment; and the use of samples containing large numbers of eggs and alevins. There is, of course, the possibility that our results with the eggs were misleading and brought about by a kill of the intra-ovum pathogen during the in vitro (broth enrichment) phase of the experiment. This possibility is, however, discounted because the experiment was designed to ensure that Rs was exposed to non-lethal levels of the antibiotic during the incubation period. (The highest concentration of the drug experienced by the bacterium during incubation was calculated to be $0.04 \mu \mathrm{g}$ $\mathrm{ml}^{-1}$, a level established in our laboratory as well below the lethal level for Rs). In addition, an in vitro kill of the pathogen would not have explained our inability 
to detect Rs cells in the treated alevin yolk samples because these samples were not subjected to an in vitro (broth enrichment) procedure.

An experiment analogous to the present one, but with naturally infected fish, is needed to see if results as promising as obtained here can be reproduced. On the basis of the present results, however, it seems reasonable to conclude that it should be possible to significantly reduce BKD problems in salmon rearing facilities if good husbandry techniques are combined with broodstock injection. These techniques include the use of a broodstock screening program to eliminate all but the most lightly infected fish, surface disinfection of the eggs, and the rearing of the progeny in waters that are not severely compromised by the presence of Rsinfected fish.

Acknowledgements. Support for this project from the Department of Fisheries and Oceans and the Department of Supply and Services (contract number FP597-7-0875/01-SB) is gratefully acknowledged.

\section{LITERATURE CITED}

Armstrong, R. D., Evelyn, T. P. T., Martin, S. W., Dorward, W. Ferguson, H. W. (1989a). Erythromycin levels in eggs and alevins derived from spawning broodstock chinook salmon (Oncorhynchus tshawytscha) injected with the drug. Dis. aquat. Org. 6: 33-36

Armstrong, R. D., Martin, S. W., Evelyn, T. P. T., Hicks, B., Dorward, W. J., Ferguson, H. W. (1989b). A field evaluation of an indirect fluorescent antibody-based broodstock screening test used to control the vertical transmission of Renibacterium salmoninarum in chinook salmon (Oncorhynchus tshawytscha). Can. J. Vet. Res. 53: 385-389

Bell, G. R., Higgs, D. A., Traxler, G. S. (1984). The effect of dietary ascorbate, zinc, and manganese on the development of experimentally induced bacterial kidney disease in sockeye salmon (Oncorhynchus nerka). Aquaculture 36: 293-311

Brown, L. L., Albright, L. J., Evelyn, T P. T (1990). Control of vertical transmission of Renibacterium salmoninarum by injection of antibiotics into maturing female coho salmon Oncorhynchus kisutch. Dis. aquat. Org. 9: 127-131

Bullock, G. L., Leek, S. L. (1986). Use of erythromycin in reducing vertical transmission of bacterial kidney disease. Vet. Hum. Toxicol. Suppl. 1: 18-20
Bullock, G. L., Stuckey, H. M., Mulcahy, D. (1978). Corynebacterial kidney disease: egg transmission following jodophore disinfection. Fish Health News 7: 51-52

Elliott, D. G., Barila, T Y. (1987). Membrane filtration-fluorccent antibody staining procedure for detecting and quantifying Renibacterium salmoninarum in coelomic fluid of chinook salmon (Oncorhynchus tshawytscha). Can. J. Fish. Aquat. Sci. 44: 206-210

Elliott, D. G., Pascho, R. J., Bullock, G. L. (1989). Developments in the control of bacterial kidney disease of salmonid fishes. Dis. aquat. Org. 6: 201-215

Evelyn, T P. $\Upsilon$ (1988). Bacterial kidney disease in British Columbia, Canada: comments on its epizootiology and methods for its control on fish farms. In: AQUA NOR 87 Trondheim International Conference, Norske Fiskeoppdretteres Forening-Fiskeoppdretternes Salgslag A/L, Trondheim, p. 51-57

Evelyn, T. P. T., Ketcheson, J. E., Prosperi-Porta, L. (1984a). Further evidence for the presence of Renibarterium salmoninarum in salmonid eggs and for the failure of povidone-iodine to reduce the intra-ovum infection rate in water-hardened eggs. J. Fish Dis. 7: 173-182

Evelyn, T P. T., Prosperi-Porta, L., Ketcheson, J. E. (1984b) The salmonid egg as a vector of the kidney disease bacterium, Renibacterium salmoninarum. In: AQUIGRUP (ed) Fish diseases, 4th COPRAQ session. EDITORA ATP, Madrid, p. 111-117

Evelyn, T P. T., Ketcheson, J. E., Prosperi-Porta, L. (1986a). use of erythromycin as a means of preventing vertical transmission of Renibacterium salmoninarum. Dis. aquat. Org. 2: 7-11

Evelyn, T P. T., Prosperi-Porta, L., Ketcheson, J. E. (1986b). Experimental intra-ovum infection of salmonid eggs with Renibacterium salmoninarum and vertical transmission of the pathogen with such eggs despite their treatment with erythromycin. Dis. aquat. Org. 1. 197-202

Lee, E. G-H. (1989). Technique for enumeration of Renibacterium salmoninarum in fish kidney tissues. J. Aquat. Anim. Health 1: 25-28

Lee, E. G-H., Gordon, M. R. (1987). Immunofluorescence screening of Renibacterium salmoninarum in tissues and eggs of farmed chinook salmon spawners. Aquaculture 65: $7-14$

Murray, C. B., Evelyn, T P. T., Beacham, T. D., Barner, L. W., Ketcheson, J. E., Prosperi-Porta, L. (1992). Experimental induction of bacterial kidney disease in chinook salmon by immersion and cohabitation challenges. Dis. aquat. Org. 12: $91-96$

Pascho, R. J., Elliott, D. G., Mallett, R. W., Mulcahy, D. (1987). Comparison of five techniques for the detection of Renibacterium salmoninarum in adult coho salmon. Trans. Am. Fish. Soc. 11: 882-890

Manuscript first received: October 12, 1992

Revised version accepted: September 30, 1993 